\title{
Ice phenomena on Lake Wielki Staw in the Valley of Five Polish Lakes
}

\author{
Adam Choiński \\ Department of Hydrology and Water Management, Adam Mickiewicz University, Dzięgielowa 27, 61-680 Poznań, Poland, \\ e-mail: choinski@amu.edu.pl
}

\begin{abstract}
The paper presents an analysis of the ice phenomena on Lake Wielki Staw in the Valley of Five Polish Lakes based on observations of the Institute of Meteorology and Water Management conducted in the years 1971-1979. The dates of commencement and decline of ice phenomena and ice cover and their persistence were determined. For 1978 and 1979, changes in the ice cover were determined, i.e. from development to decline. Due to the close vicinity of Lake Morskie Oko, comparisons were performed in terms of variability of ice phenomena of both of the lakes. The study showed among others that although Lake Wielki Staw is located higher than Lake Morskie Oko by approximately $270 \mathrm{~m}$, ice phenomena on the lake appear on the average 10 days later than in Lake Morskie Oko, and the mean persistence of the ice cover is the same, i.e. it amounts to 167 days.
\end{abstract}

Key words: ice phenomena, Lake Wielki Staw, Tatra Mountains

\section{Introduction}

Considering Polish conditions, Lake Wielki Staw (The Great Polish Lake) in the Valley of Five Polish Lakes is included among high mountain lakes. Unfortunately, the results of studies of this type of lake are scarce. This is due to their considerable inaccessibility, particularly in winter, when the route to the lakes is covered with deep snow and patches of ice, and is prone to avalanche threat. In such a situation the only possibility to carry out continuous measurements is to perform them from a shelter functioning all year round irrespective of weather conditions. One of the scarce examples of the type in the Polish Tatra Mountains is Schronisko Pięciostawiańskie (Five Lakes Shelter) at the shore of Lake Przedni Staw in the Valley of Five Polish Lakes. It is the highest mountain shelter in Poland, at an altitude of $1671 \mathrm{~m}$ a.s.l. Its location allows year-round observations of Lake Wielki Staw to be conducted at a distance of only $400 \mathrm{~m}$ from the shelter. In the aforementioned case, this concerned observations of water stages and ice phenomena. It is worth mentioning that continuous observations are conducted only on Lake Morskie Oko, and in the past also on Lake Zielony Staw on Hala Gąsienicowa (Gąsienicowa Meadows), and on Lake Wielki Staw.
In reference to ice phenomena, apart from continuous research, measurements in mountain lakes were performed sporadically, e.g. while taking measurements of water temperature and oxygen content under the ice, or with hydrobiological research. On 12 May 1938 on Lake Zadni Staw in the Valley of Five Polish Lakes, Olszewski (1946) encountered ice with a thickness of $3.6 \mathrm{~m}$, which is considered the maximum ice thickness recorded in Poland. It should be emphasised, however, that such thick ice develops through accumulation of snow layers on primary ice. The layers are saturated with water outflowing through ice fissures as a result of the load of snow on the ice cover. At very low temperatures, the wet snow mass freezes. As a result of repetition of the phenomenon, several layers of ice develop, separated from one another with layers of partially frozen snow. Lityński (1917) recorded ice with a thickness of $2.0 \mathrm{~m}$ on the frozen Lake Zamarzły Staw Gąsienicowy, and on 21 March 1911 of $2.7 \mathrm{~m}$ on Lake Zielony Staw Gąsienicowy. On 15 March 1938, Olszewski (1946) drilled layer ice with a thickness of $1.1 \mathrm{~m}$ on Lake Czarny Staw pod Rysami (Black Lake under Mount Rysy), and on 6 May 1938, 2.5 m (Pacl and WitJóźwik 1974). According to the paper by the aforementioned authors, on 10 May 1938, Szaflarski drilled ice with a thickness of $1 \mathrm{~m}$ on Lake Wielki Staw. One of the 


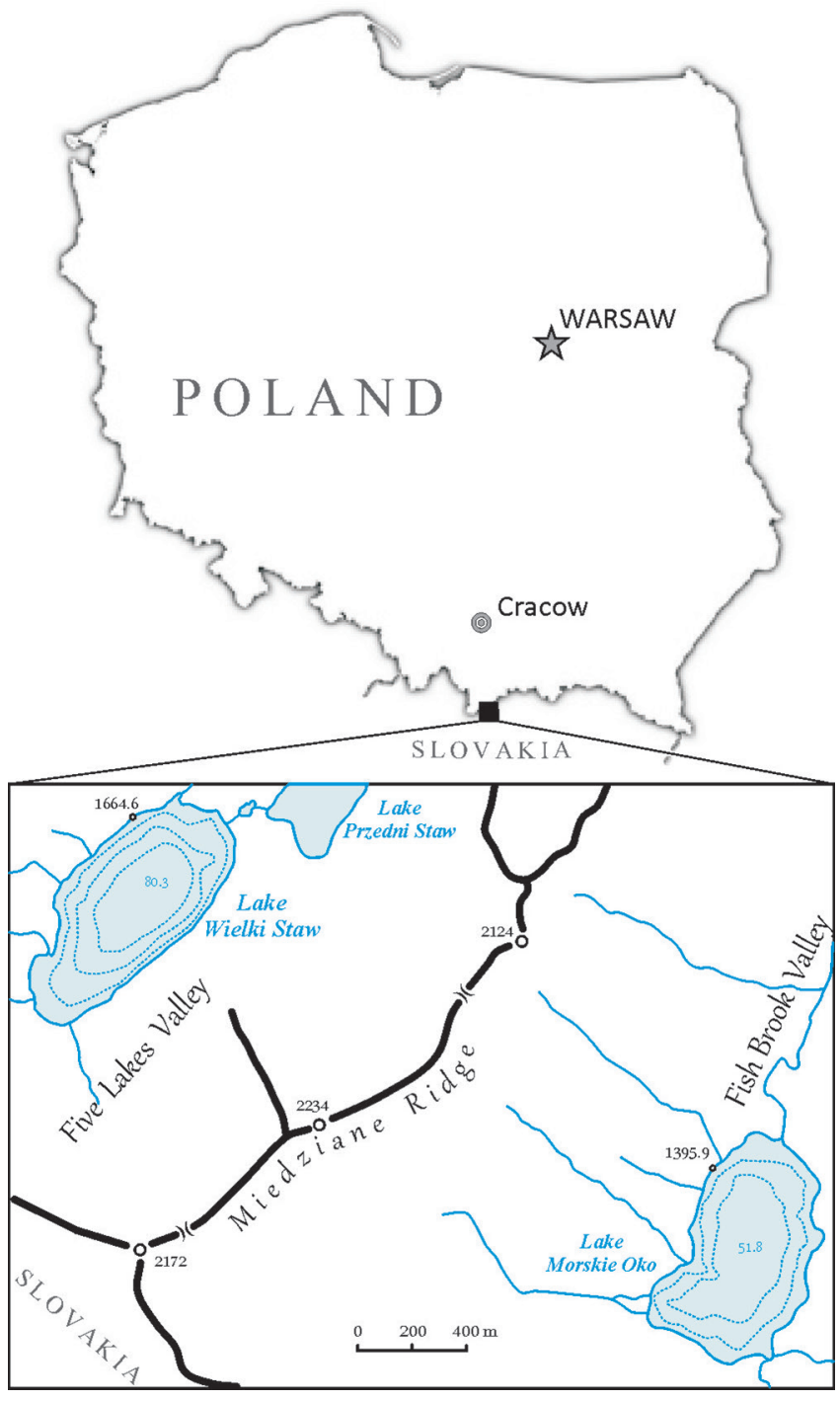

Fig. 1. Location of the studied lakes

papers concerning ice phenomena in the Tatra Mountains is a study by Choiński (2016). The author determined the variability of the ice cover on Lake Czarny Staw at the foot of the Rysy Mountain.

The quite commonly recorded tendency for an increase in lake water temperature resulting from climate warming also concerns high mountain lakes (Verburg et al. 2003; Coasts et al. 2006; Keller 2007). A consequence of such transformations is the evolution and transformation of lake ecosystems (Thompson et al. 2005).

The objective of this paper is to determine the variability of ice phenomena in the course of winter and in particular years. Moreover, the paper presents a comparison of the analysed phenomena to those occurring in Lake Morskie Oko located nearby, although almost $270 \mathrm{~m}$ below the level of Lake Wielki Staw (Fig. 1).

In addition to the determination of ice phenomena, the paper compares them to those occurring in Lake
Morskie Oko. This will help to answer the question as to whether in spite of the great difference between them, the course of ice phenomena is similar or different, or perhaps determined by local factors. It should be mentioned that in terms of the area of the catchment and the lakes themselves, differences between them amount to only a few percent. The objects are comparable in these terms.

\section{Study area and methods}

Due to the morphometric parameters of its basin and location (1664.6 $\mathrm{m}$ a.s.l.), Lake Wielki Staw in the Valley of Five Polish Lakes evidently stands out among Polish lakes. It is the deepest lake in the Tatra Mountains - $80.3 \mathrm{~m}$ (Choiński 2000), and the third deepest lake in Poland. In terms of mean depth $-37.7 \mathrm{~m}-$ it is second after Lake Hańcza (38.7 m), and in terms of mean inclination, it takes the $4^{\text {th }}$ position (Choiński 2007). The area of its catchment amounts to $5.5 \mathrm{~km}^{2}$. The lake itself is the second largest lake in the Polish Tatra Mountains after Lake Morskie Oko, and its basin accumulates the largest water resources, i.e. approximately 13 million $\mathrm{m}^{3}$. The lake is surrounded by high peaks reaching 500-600 $\mathrm{m}$ above the water surface. The Kozi Wierch Mountain (2291 $\mathrm{m}$ a.s.l.) is located only $1.1 \mathrm{~km}$ to the north-west in straight line from the lake's shore, constituting the highest peak in Poland located entirely in Polish territory. Lake Wielki Staw is considerably more prone to the effect of external factors than Lake Morskie Oko, although so-called exposure (openness) indices, defined as the ratio of the lake's surface area to its mean depth, amount to 0.91 and 1.23 , respectively. In the above case, the greater openness of Lake Wielki Staw to the effect of climate factors (e.g. insolation or wind) results from the considerably "tighter" surroundings of Lake Morskie Oko, sheltered by the peaks around it. Altitude differences between its water surface and the highest peaks exceed $1000 \mathrm{~m}$. In the case of Lake Wielki Staw, they are approximately twice lower. Moreover, due to similar ordinates, the lakes: Czarny Staw Polski, Wielki Staw, and Przedni Staw, located in one sequence, provide space (approximately $3 \mathrm{~km}$ in length) for free activity of wind. Therefore, Lake Wielki Staw has more favourable conditions both for higher insolation, and more intensive circulation in the basin.

On 1 October 1967, the Institute of Meteorology and Water Management commenced observations of water stages. Data concerning ice phenomena from 1 October 1971 are available. The observations were completed in 1979. They cover nine full hydrological years. The results of the observations were published by the Institute of Meteorology and Water Management (IMGW 1971-1979). The observations concerned: the date of 
appearance and disappearance of ice phenomena and ice cover every five days. Materials for analysis were obtained in accordance with the guidelines adopted by the aforementioned Institute, binding in Poland for the last approximately 100 years.

In spite of a short observation period, analysing the obtained results is justified. It is a hydrological object with the highest location in Poland, subject to continuous observation lasting several years.

\section{Results and discussion}

Table 1 presents parameters of the ice cover on Lakes Wielki Staw and Morskie Oko. In the case of the latter, the parameters were determined for the same period, i.e. for the years 1971-1979, so that the obtained results can be comparable. On Lake Wielki Staw, the phenomena appear on 23 November on average, whereas the range was from 15 November to 15 December. They disappear on 10 June on average, at a temporal range from 20 May to 25 June. Average, ice phenomena last for 200 days in a year (min. from 170 days in 1971, max. to 223 days in 1973). The ice cover appears very soon after the commencement of ice phenomena, i.e. after seven days, on average on 30 November, at a range from 25 November to 20 December. It persists for an average of 167 days in a year (min. from 141 days in 1977 to max. 227 days in 1975). It generally disappears on 16 May at a range from 19 April (in 1972) to 4 June (in
1974). Therefore on average, the ice cover is destructed 26 days before the date of decline of ice phenomena. In the case of Lake Morskie Oko, it might seem surprising that ice phenomena appear on average 10 days earlier than on the considerably higher Lake Wielki Staw. The phenomenon can be explained by the fact that Lake Morskie Oko is substantially more isolated from the effect of external factors, which results in a more rapid cooling of its waters. Moreover, the near-shore zone in Lake Morskie Oko is considerably shallower than in Lake Wielki Staw (isobaths 5 and $10 \mathrm{~m}$ are located considerably closer to the shore). This contributes to faster water cooling. In the case of decline of ice phenomena, the situation is the opposite, i.e. their decline occurs 15 days earlier in Lake Morskie Oko. This in turn is associated with thicker, and therefore more durable ice cover, and other forms of ice on Lake Wielki Staw. The ice cover itself, similarly to ice phenomena, develops on Lake Wielki Staw eight days later than on Lake Morskie Oko, although it declines six days later (16 May) than on Lake Morskie Oko (10 May). In the analysed period, i.e. 1971-1979, the duration of ice phenomena was several days longer in Lake Wielki Staw, and the ice cover persisted for the same periods of time in both of the lakes, i.e. 167 days. In reference to the maximum ice thickness values, mean values from the entire analysed period cannot be compared. For the years 1978 and 1979, however, the maximum ice thickness values for Lake Wielki Staw are higher by approximately $20 \mathrm{~cm}$

Table 1. Parameters of the ice cover of Lake Wielki Staw and Morskie Oko in the years 1971-1979 according to IMGW (1971-1979), Choiński et al. (2014)

\begin{tabular}{|c|c|c|c|c|c|c|c|}
\hline \multicolumn{8}{|c|}{ Lake Wielki Staw } \\
\hline \multirow{2}{*}{ Year } & \multicolumn{2}{|c|}{ Ice phenomena } & \multicolumn{2}{|c|}{ Ice cover } & \multirow{2}{*}{ Maximum ice thickness [cm] } & \multicolumn{2}{|c|}{ Duration [days] } \\
\hline & Beginning & End & Beginning & End & & Ice phenomena & Ice cover \\
\hline 1971 & $25 \mathrm{XI}$ & $20 \mathrm{~V}$ & $30 \mathrm{XI}$ & $1 \mathrm{~V}$ & n.d. & 170 & 153 \\
\hline 1972 & $20 \times I$ & $25 \mathrm{~V}$ & $30 \times I$ & 19 IV & n.d. & 188 & 142 \\
\hline 1973 & $15 X I$ & $25 \mathrm{VI}$ & $25 \mathrm{XI}$ & $14 \mathrm{~V}$ & n.d. & 223 & 171 \\
\hline 1974 & $25 X I$ & $25 \mathrm{VI}$ & $30 \mathrm{XI}$ & $4 \mathrm{VI}$ & n.d. & 213 & 187 \\
\hline 1975 & $1 \mathrm{XI}$ & $15 \mathrm{VI}$ & $1 \mathrm{XI}$ & $24 \mathrm{~V}$ & n.d. & 227 & 205 \\
\hline 1976 & $30 \mathrm{XI}$ & $15 \mathrm{VI}$ & 10 XII & $29 \mathrm{~V}$ & n.d. & 199 & 172 \\
\hline 1977 & $15 X I I$ & $14 \mathrm{VI}$ & $20 \times 11$ & $19 \mathrm{~V}$ & n.d. & 182 & 141 \\
\hline 1978 & $20 X I$ & $10 \mathrm{VI}$ & $25 \mathrm{XI}$ & $19 \mathrm{~V}$ & 97 & 203 & 176 \\
\hline \multirow[t]{2}{*}{1979} & $25 X I$ & $5 \mathrm{VI}$ & $10 X I I$ & $14 \mathrm{~V}$ & 100 & 193 & 156 \\
\hline & $23 \times \mathrm{XI}$ & $10 \mathrm{VI}$ & $30 \mathrm{XI}$ & $16 \mathrm{~V}$ & - & 200 & 167 \\
\hline \multicolumn{8}{|c|}{ Lake Morskie Oko } \\
\hline 1971 & $17 \mathrm{XI}$ & $12 \mathrm{~V}$ & $27 \mathrm{XI}$ & $24 \mathrm{IV}$ & 68 & 177 & 149 \\
\hline 1972 & $20 \times I$ & $24 \mathrm{~V}$ & $1 X I I$ & $1 \mathrm{~V}$ & 72 & 179 & 153 \\
\hline 1973 & $9 \times \mathrm{XI}$ & $23 \mathrm{~V}$ & $25 X I$ & $19 \mathrm{~V}$ & 69 & 196 & 169 \\
\hline 1974 & $1 \mathrm{XI}$ & $30 \mathrm{~V}$ & $4 X I$ & $26 \mathrm{~V}$ & 60 & 211 & 179 \\
\hline 1975 & $1 \mathrm{XI}$ & $24 \mathrm{~V}$ & $8 X I$ & $5 \mathrm{~V}$ & 92 & 203 & 179 \\
\hline 1976 & $22 \mathrm{XI}$ & $5 \mathrm{VI}$ & $24 X I$ & $4 \mathrm{~V}$ & 75 & 192 & 161 \\
\hline 1977 & $29 X I$ & $30 \mathrm{~V}$ & $6 \times 11$ & $12 \mathrm{~V}$ & 61 & 169 & 158 \\
\hline 1978 & $14 \mathrm{XI}$ & $4 \mathrm{VI}$ & $28 X I$ & $20 \mathrm{~V}$ & 84 & 193 & 174 \\
\hline \multirow[t]{2}{*}{1979} & $2 \mathrm{XI}$ & $23 \mathrm{~V}$ & $11 X I$ & $11 \mathrm{~V}$ & 74 & 203 & 182 \\
\hline & $13 \mathrm{XI}$ & $26 \mathrm{~V}$ & $22 \mathrm{XI}$ & $10 \mathrm{~V}$ & 73 & 191 & 167 \\
\hline
\end{tabular}

n.d. - no data. 
Table 2. Comparison of mean temperatures (in Celsius degrees) for the years 2005-2010 according to data of the Institute of Meteorology and Water Management

\begin{tabular}{lccc}
\hline \multirow{2}{*}{ Month/Season } & \multicolumn{2}{c}{ Surroundings } & Absolute differences in air temperatures between the vicinity of Wielki Staw and Morskie Oko \\
\cline { 2 - 3 } January & -5.5 & -5.3 & 0.2 \\
February & -6.5 & -5.8 & 0.7 \\
March & -4.9 & -3.8 & 0.9 \\
April & 1.3 & 2.2 & 0.9 \\
May & 5.7 & 6.6 & 0.9 \\
June & 9.2 & 10.2 & 1.0 \\
July & 12.0 & 12.8 & 0.8 \\
August & 10.7 & 11.5 & 0.8 \\
September & 6.7 & 7.6 & 0.9 \\
October & 3.3 & 4.0 & 0.7 \\
November & -0.1 & 1.6 & 1.5 \\
December & -4.5 & -4.3 & 0.2 \\
\hline Spring (III-V) & 0.7 & 1.7 & 1.0 \\
Summer (VI-VIII) & 10.6 & 11.5 & 0.9 \\
Autumn (IX-XI) & 3.3 & 4.4 & 0.9 \\
Winter (XII-II) & -5.5 & -5.1 & 0.4 \\
\hline Year & 2.3 & 3.1 & 0.8 \\
\hline
\end{tabular}

than those measured on Lake Morskie Oko. The possibility of comparison of air temperatures at Lake Morskie Oko and Lake Wielki Staw seems to be exceptionally valuable. In this case, data of daily measurements for the years 2005-2010 were obtained. They permitted the determination of mean monthly, seasonal, and annual temperatures for both of the lakes - Table 2 .

Throughout the period of occurrence of ice phenomena, i.e. from November to June - during eight months, the air temperature in the vicinity of Lake Wielki Staw was lower than at Lake Morskie Oko. The differences are inconsiderable, however, oscillating between $0.2^{\circ} \mathrm{C}$ (January, December) and $1.5^{\circ} \mathrm{C}$ (November). This also concerns seasons in which in winter the difference is the lowest, i.e. the vicinity of Lake Morskie Oko is warmer by only $0.4^{\circ} \mathrm{C}$, and in spring the difference reaches $1.0^{\circ} \mathrm{C}$. With respect to the mean annual temperature from the multiannual 2005-2010, at Lake Morskie Oko it amounts to $3.1^{\circ} \mathrm{C}$, and at Lake Wielki Staw to $2.3^{\circ} \mathrm{C}$. Small differences in air temperatures (in spite of a significant difference in altitude between the lakes) largely account for the fact of inconsiderable differences in the occurrence of ice phenomena on both of the lakes, i.e. duration of ice phenomena longer by approximately $5 \%$ (in the case of Lake Wielki Staw) at the same persistence of ice cover.

By conducting measurements of ice thickness every five days in the years 1978 and 1979 it is possible to track the development of the ice cover from the initial ice development to its decline - Fig. 2.

The process of development of the ice cover in the analysed years is similar. The differences between the years result from variable weather conditions - they occur both during a given winter and the preceding

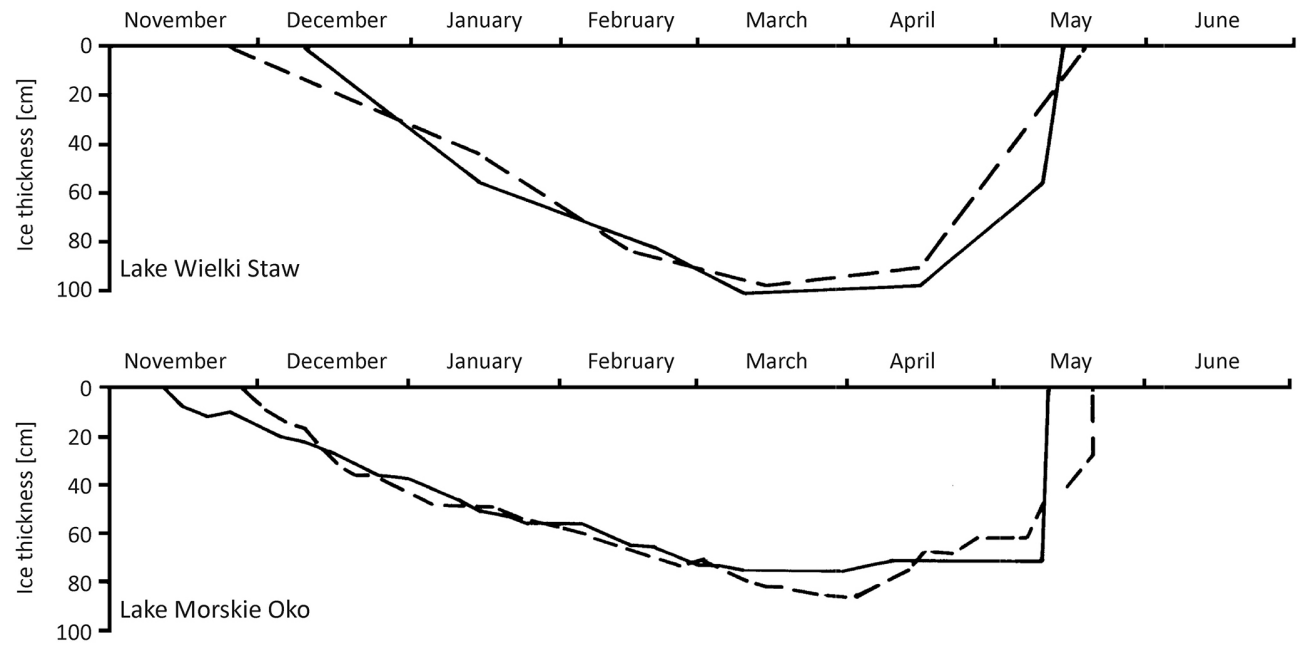

Fig. 2. Development and decline of the ice cover on Lakes Wielki Staw and Morskie Oko in the years 1978 (broken line) and 1979 (solid line) 


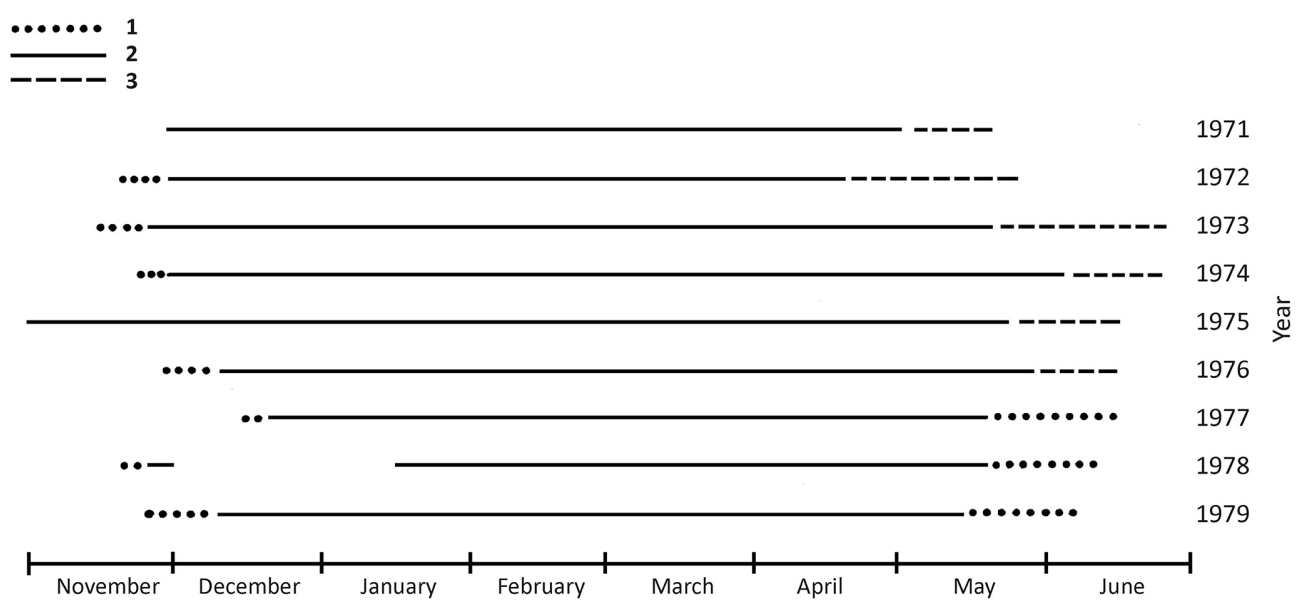

Fig. 3. Forms of the ice in Lake Wielki Staw in the years 1971-1979. Explanation: 1 - frazil ice, 2 - ice cover, 3 - floating ice

period, determining the heat balance of the lake at the beginning of winter. The process of development of the ice cover usually commences in November. It is followed by an average of approximately four months of ice thickness growth. The maximum thickness is reached in March. Decline of the ice begins from that moment, when it occurs approximately twice or three times faster than the growth phase. The most intensive decline takes place in the final period when ice with a thickness of 50-70 cm melts over the course of just a few days. This certainly results from its weak structure, which combined with the wave action causes rapid destruction of the ice cover, developing floating ice. The greatest visible difference between the ice cover of Lake Wielki Staw and Lake Morskie Oko is certainly its thickness. In the former case, it is greater by approximately $20 \%$ in the entire cycle.

Fig. 3 presents forms of ice as components of the observed ice phenomena in Lake Wielki Staw, including: frazil ice, ice cover, and floating ice. The highest contribution in the total ice phenomena is reached by ice cover. Its mean contribution amounts to $83.5 \%$, whereas the lowest $-75.5 \%$ was observed in 1972 , and the highest, i.e. $90.3 \%$ in 1975.

Fig. 4 presents the courses of the duration of occurrence of ice phenomena and ice cover in the years 1971-1979 for Lakes Wielki Staw and Morskie Oko. In the case of Lake Morskie Oko, both of the curves have generally similar courses. Curves for Lake Wielki Staw show deviations from the rule (years 1972 and 1974), involving mutually inversive values of points on curves. Courses of the curves for both Lake Wielki Staw and Lake Morskie Oko show increasing trends, but they are not statistically significant $(\mathrm{p}>0.05)$. Trends for Lake Morskie Oko are more evident, i.e. for ice phenomena: $\mathrm{p}=0.534, \mathrm{r}^{2}=0.06$, and for ice cover: $\mathrm{p}=0.104, \mathrm{r}^{2}$ $=0.34$. Although in general the courses of the curves show an increase in the duration of occurrence of both ice phenomena and ice cover, such conclusions should be treated with caution. The analysis of ice phenomena performed for Lake Morskie Oko for the years 19712010 (Choiński et al. 2014) shows an opposite trend, i.e. over 40 years, an evident tendency for reduction of the persistence of ice phenomena is observed - on average nine days per decade, and reduction of the persistence of ice cover - on average 9.5 days per decade. The tendency also concerns a decrease in the maximum thickness of the ice cover - on average by $2.2 \mathrm{~cm}$ per decade. According to the above comparison, the analysed time period (1971-1979) against the background of the multiannual period (1971-2010) was located in the part with an inconsiderable tendency for an increase in the duration of the occurrence of ice phenomena. If the courses of ice phenomena in the years 1971-1979 in Lake Wielki Staw and Lake Morskie Oko are mutually parallel, it can be assumed that the phenomena in Lake Wielki Staw at a longer time scale (1971-2010) have a tendency for reduced duration. The above example suggests that no definite conclusions should be drawn from data from short observation series. They are not necessarily in accordance with the results of a long series, and can even be inversive, as shown in the above example.

\section{Conclusions}

The paper presents the analysis of ice phenomena in Lake Wielki Staw and the Valley of the Five Polish Lakes based on data of IMGW for the years 1971-1979. Lake Wielki Staw is a hydrological object with the highest location in Poland (1664.6 m a.s.1.), subject to continuous observations. The mean duration of occurrence of ice phenomena in a year amounted to 200 days, and ice cover to 167 days. This constitutes $83.5 \%$ of the persistence of all ice phenomena. Dates of appearance of ice phenomena average 23 November, and their decline 10 June, analogically to the dates in reference to the ice 

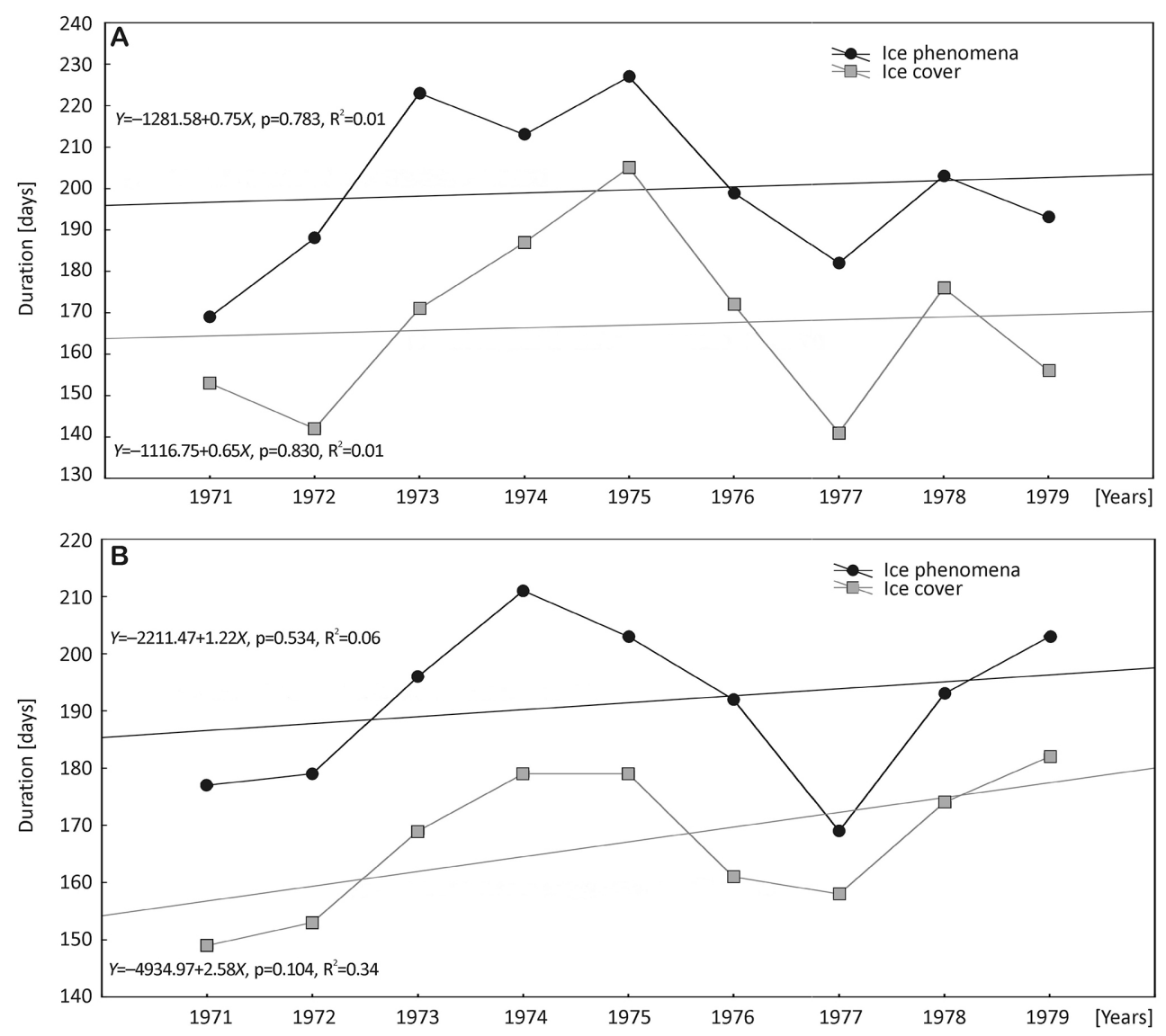

Fig. 4. Persistence of ice phenomena and ice cover on Lakes Wielki Staw (A) and Morskie Oko (B)

cover: 30 November and 16 May. The process of growth of the ice cover thickness lasts for approximately four months, and its maximum thickness is reached in March. The phase of its decline occurs approximately twice as fast as the growth phase, i.e. amounts to approximately two months. The analysis of the mean annual durations of occurrence of ice phenomena and ice cover shows their increasing, although not statistically significant trends. Data obtained for Lake Wielki Staw were compared with data for Lake Morskie Oko for the analogical period. Similarities and differences in the course of the analysed phenomena were marked. In Lake Morskie Oko, in spite of its location lower by approximately $270 \mathrm{~m}$, ice phenomena were observed to commence 10 days earlier than in Lake Wielki Staw. The difference may result from local conditions, determining the heat balance of both of the lakes. Although an increasing trend of the persistence of ice phenomena and ice cover was obtained for both of the lakes, it only concerns a short analysed period of time. The analysis performed for Lake Morskie Oko for the years 1971-2010 showed an opposite trend, i.e. reduction of persistence of ice phenomena and ice cover. The example shows that the analysis of observations from short periods of time may provide results completely different than in the case of longer series.

In different regions of the Earth, a phenomenon evidencing modern climate warming is the retreat of glaciers. In the Tatra Mountains, where no glaciers occur, climate changes are "recorded" in ice cover on lakes. This fact justifies the performance of these types of measurements and their analysis.

\section{References}

Choiński A., 2000, Najgłębsze jeziora Tatr polskich w świetle najnowszych pomiarów głębokościowych (The deepest lakes of the Polish Tatra Mountains in the context of the latest depth measurements), Czas. Geogr. 71(1): 99-103 (in Polish, English summary).

Choiński A., 2007, Limnologia fizyczna Polski (Physical limnology of Poland), Wydaw. Nauk. UAM, Poznań, 540 pp (in Polish).

Choiński A., 2016, Ice phenomena on Lake Czarny Staw pod Rysami, Limnol. Rev. 16(3): 165-169.

Choiński A., Pociask-Karteczka J., Ptak M., Strzelczak A., 2014, Zjawiska lodowe na Morskim Oku (Ice phenomena on Lake Morskie Oko), [in:] Choiński A., Pociask- 
Karteczka J. (eds), Morskie Oko - przyroda i człowiek (Morskie Oko - nature and a man), Wydaw. TPN, Zakopane: 66-79 (in Polish).

Coats R., Perez-Losada J., Schladow G., Richards R, Goldman C., 2006, The warming of Lake Tahoe, Clim. Change 76(1-2): 121-148.

[IMGW] Instytut Meteorologii i Gospodarki Wodnej (Institute of Meteorology and Water Management), 19711979, Roczniki hydrologiczne wód powierzchniowych. Dorzecze Wisły i rzek Przymorza na wschód od Wisły (Hydrological yearbooks of surface waters. The Vistula basin and the rivers of the coast region east of the Vistula River), WKiŁ, Warszawa (in Polish).

Keller W., 2007, Implications of climate warming for Boreal Shield lakes: A review and synthesis, Environ. Rev. 15(1): 99-112.
Lityński A., 1917, Jeziora tatrzańskie i zamieszkująca je fauna wioślarek (Lakes of the Tatra Mountains and their Cladocera fauna), Spraw. Kom. Fizjogr. PAU 51: 1-88 (in Polish).

Olszewski P., 1946, Zimowe stosunki tlenowe większych jezior tatrzańskich (Oxygen conditions in winter in the largest lakes in the Tatra Mountains), Rozpr. Wydz. Mat.Przyr. PAU 72A(7): 1-80 (in Polish, English summary).

Pacl J., Wit-Jóźwik W., 1974, Teplota vôd (Temperature of water), [in:] Konček M. (ed.), Klimat Tatr (Tatras climate), Veda Vydav. SAV, Bratislava: 181-204 (in Slovakian).

Thompson R., Kamenik C., Schmidt R., 2005, Ultra-sensitive Alpine lakes and climate change, J. Limnol. 64(2): 139152.

Verburg P., Hecky R.E., Kling H., 2003, Ecological consequences of a century of warming in Lake Tanganika, Science 301: 505-507. 